\title{
Human papillomavirus is frequently detected in gefitinib-responsive lung adenocarcinomas
}

\author{
MICHIHIRO BABA ${ }^{1}$, ANDRES CASTILLO ${ }^{2}$, CHIHAYA KORIYAMA $^{2}$, MASAKAZU YANAGI $^{1}$, \\ HIDEHIKO MATSUMOTO ${ }^{1}$, SHOJI NATSUGOE ${ }^{1}$, KAREM Y. SHUYAMA ${ }^{2}$, NOUREEN KHAN ${ }^{2}$, \\ MICHIYO HIGASHI ${ }^{3}$, TETSUHIKO ITOH ${ }^{4}$, YOSHITO EIZURU ${ }^{4}$, TAKASHI AIKOU ${ }^{1}$ and SUMINORI AKIBA ${ }^{2}$ \\ Departments of ${ }^{1}$ Surgical Oncology and Digestive Surgery, ${ }^{2}$ Epidemiology and Preventive Medicine and \\ ${ }^{3}$ Human Pathology, Graduate School of Medical and Dental Sciences, Kagoshima University, \\ 8-35-1 Sakuragaoka, Kagoshima 890-8544; ${ }^{4}$ Kodama Hospital, Kagoshima, Japan
}

Received November 26, 2009; Accepted December 29, 2009

DOI: $10.3892 /$ or_00000736

\begin{abstract}
A number of studies have reported the presence of human papillomavirus (HPV) in lung carcinoma. Interestingly, its detection rate appears to differ histologically and geographically. The present study examined 30 adenocarcinomas and 27 squamous cell carcinomas of the lung in a southern area of Japan, and detected high-risk HPV genome in 9 $(30 \%)$ adenocarcinomas and $2(7 \%)$ squamous cell carcinomas, using PCR with SPF10 primers and INNO-LiPA HPV genotyping assay. The difference of HPV detection rates in adenocarcinomas and squamous cell carcinomas was statistically significant ( $\mathrm{P}=0.044$, Fisher's exact test). HPV-16 was the most prevalent HPV genotype, and was detected in $27 \%(8 / 30)$ of adenocarcinomas and in 7\% (2/27) of squamous cell carcinomas. High-risk-HPV positive carcinomas had decreased proportions of $\mathrm{pRb}(\mathrm{P}=0.107)$ and significantly increased proportions of $\mathrm{p} 16^{\mathrm{INK} 4 \mathrm{a}}$ expressing cells $(\mathrm{P}=0.031)$ when compared to HPV-negative lung carcinomas. All HPV-16positive cases were considered to have an integrated form of HPV-16 but its viral load was low (geometric mean $=0.02$ copy per cell). In 20 additional adenocarcinomas treated with gefitinib, a tyrosine kinase inhibitor specific for epidermal growth factor receptor, the presence of HPV was examined. Note that East Asian ethnicity is a predictive factor of gefitinib response. High-risk HPV genome was found in $75 \%$ $(6 / 8)$ of adenocarcinomas with complete or partial response to gefitinib but was not found in the remaining 12 , which did not respond to gefitinib. In conclusion, the present study suggests that high-risk HPV may be more strongly related to
\end{abstract}

Correspondence to: Dr Chihaya Koriyama, Department of Epidemiology and Preventive Medicine, Graduate School of Medical and Dental Sciences, Kagoshima University, 8-35-1 Sakuragaoka, Kagoshima 890-8544, Japan

E-mail: fiy@m.kufm.kagoshima-u.ac.jp

Key words: human papillomavirus, lung, adenocarcinoma, gefitinib adenocarcinomas, particularly gefitinib-responsive adenocarcinomas, when compared to squamous cell carcinomas. However, its low viral load makes it difficult to determine the etiological significance of these findings.

\section{Introduction}

A number of studies have reported the presence of human papillomavirus (HPV) in lung carcinoma. Its detection rate appears to differ histologically and geographically $(1,2)$. An evident geographical difference was pointed out in a recent meta-analysis by Klein et al (1), who reviewed 53 publications reporting on 4508 cases; HPV was detected in 17,15 and $36 \%$ of lung carcinomas in Europe, USA and Asia, respectively. Particularly high frequencies of up to $80 \%$ were seen in Okinawa (Japan), southern islands of Japan, and Taichung in Taiwan, which is only a few hundred kilometers away from Okinawa islands. Histological differences were reported by another meta-analysis reviewing all studies reported until 2001 (2). This report revealed that HPV was positive in $25 \%$ of squamous cell carcinomas (SQCs), $19 \%$ of small cell carcinomas (SCLCs) and $8 \%$ of adenocarcinomas (ACs). Regarding histological predisposition, an interesting finding was made by a study in Okinawa, which reported that HPV involvement in cancer of the lung is most evident in well-differentiated SQCs, frequency of which has declined over the years (3). On the other hand, a study in Taiwan detected HPV-16 and HPV-18 in 43 and $49 \%$ of ACs, respectively, and in 24 and $29 \%$ of SQCs, respectively, suggesting that ACs in Taiwan harbours high-risk HPVs more frequently than SQCs (4). In this study, lung cancer among non-smoking Taiwanese women tended to be HPV$16 / 18$ positive. It is worth noting that those clinicopathological features are similar to that observed for ACs responsive to gefitinib, a tyrosine kinase inhibitor specific for epidermal growth factor receptor (EGFR) $(5,6)$.

According to a large-scale international study (7), more than $99 \%$ of cervical carcinomas were reported to harbour HPV and the persistent infection with high-risk HPV is considered as its 'necessary cause' $(8,9)$. The recent IARC monograph concluded that there was sufficient evidence in 
humans for the carcinogenicity of HPV-16, -18, -31, -33, -35, $-39,-45,-51,-52,-56,-58,-59$ and -66 in the cervix (10). Those high-risk HPVs are frequently integrated in cervical carcinomas whereas low-risk HPVs in the episomal form are usually found in benign lesions (11). On the other hand, the etiological significance of HPV in lung carcinogenesis is yet unclear. Interestingly, however, HPV integration in the host genome has been reported in lung carcinomas (12).

The expressions of HPV E6 and $E 7$ genes, important HPV oncogenes, are regulated by HPV E2 gene, whose disruption is caused by HPV genome integration into the host genome. In cervical carcinogenesis, abnormal expressions of E6 and E7 oncoproteins, induced by loss of functional E2 gene, are considered major steps for facilitating transformation and transition into a malignant state $(13,14)$. The HPV E6 oncoprotein interacts with the p53 tumor suppressor protein and the E6associated protein, a host-cell ubiquitin ligase, and accelerates proteasomal degradation of p53 (15). The importance of p53 degradation in HPV-related lung carcinogenesis was suggested by a recent study of lung carcinomas diagnosed in Taiwan, which showed an inverse correlation between HPV-16/18 E6 expression and p53 expression (16). Another important oncoprotein of HPV is E7, whose binding with $\mathrm{pRb}$ destabilizes this tumor suppressor protein (17) and induces E2F release and subsequent $\mathrm{p} 16^{\mathrm{INK} 4 \mathrm{a}}$ over-expression (18). Sano et al reported that high-risk HPV was associated with a stronger expression of $\mathrm{p} 16^{\mathrm{INK} 4 \mathrm{a}}$ in cervical carcinoma when compared to low-risk HPV (19).

In the present study, we investigated the prevalence of HPVs and their genotypes in Japanese lung carcinomas by broad spectrum and highly sensitive SPF10 primers, and HPV-16-specific primer sets. Furthermore, using real-time PCR, we estimated viral load, and determined the physical status of high-risk HPV-16 on the basis of the method proposed by Peitsaro et al (20). In addition, 20 recurrent AC cases treated with gefitinib were also examined for HPV presence.

\section{Materials and methods}

Clinical specimens. The present study examined a total of 57 paraffin-embedded tissue samples of lung carcinoma cases, 27 SQCs and 30 ACs cases, diagnosed at Kagoshima University Hospital during the period from January 1994 to February 1996. In addition, primary lung ACs obtained from 20 recurrent cases treated with gefitinib were also examined. Information on clinicopathological features and smoking habits was retrieved from pathological and medical records. Histological classification for lung carcinoma was made using the guideline determined by the Japan Lung Cancer Society (21). Institutional Review Board of Kagoshima University Graduate School of Medical and Dental Sciences, Japan, approved the present study.

DNA extraction. Sections (10 $\mu \mathrm{m}$-thick) of each paraffinembedded tissue specimen, containing a minimum of $40 \%$ (typically 60-70\%) tumor cells, were cut and collected in sterile tubes. For DNA extraction, each sample was treated with $0.8 \mathrm{ml}$ of lemosol and $0.2 \mathrm{ml}$ of ethanol, and subsequently washed with $1 \mathrm{ml}$ of ethanol. After centrifugation and air-drying, the pellet was re-suspended in digestion buffer (50 mM Tris-Cl, pH 8.0, $1 \mathrm{mM}$ EDTA, pH 8.0 and $0.5 \%$ Tween-20) containing $200 \mu \mathrm{g} / \mathrm{ml}$ of proteinase $\mathrm{K}$ (Invitrogen Corp., Carlsbad, CA, USA) and incubated at $55^{\circ} \mathrm{C}$ for $24 \mathrm{~h}$. After being heated at $100^{\circ} \mathrm{C}$ for $10 \mathrm{~min}$, the solution was subjected to phenol-chloroform extraction and DNA ethanol precipitation. The quality of DNA and the absence of PCR inhibitors in samples were checked by PCR for $\beta$-globin using PCO3 5'-ACA CAA CTG TGT TCA CTA GC-3' and PCO4 5'-CAA CTT CAT CCA CGT TCA CC-3' primers under the following PCR conditions: initial denaturation at $95^{\circ} \mathrm{C}$ for $15 \mathrm{~min}, 40$ cycles with the cycling profile of $95^{\circ} \mathrm{C}$ for $1 \mathrm{~min}, 52^{\circ} \mathrm{C}$ for $1 \mathrm{~min}, 72^{\circ} \mathrm{C}$ for $1 \mathrm{~min}$, and final extension for $5 \mathrm{~min}$ at $72^{\circ} \mathrm{C}$.

HPV detection and genotyping. The HPV genome was detected with a broad-spectrum SPF10-biotinylated primer PCR (22). The PCR products, 65 bp of the $L 1$ gene, were run on a $3 \%$ agarose gel and visualized with ethidium bromide staining by electrophoresis. HPV typing of the HPV DNApositive samples was performed using the INNO-LiPA HPV Genotyping v2 test (Innogenetics, Ghent, Belgium), which permits specific detection of $25 \mathrm{HPV}$ genotypes (HPV types $6,11,16,18,3133,35,39,40,42,43,44,45,51,52,53,54$, $56,58,59,66,68,70,73$ and 74). The details were described previously (23).

Quantitative real-time PCR. To estimate the viral load and to determine the physical status of HPV-16, quantitative realtime PCR was performed with the ABI PRISM 7700 Sequence Detection System (Applied Biosystems, Foster City, USA). The physical status of HPV-16 was determined by the method proposed by Peitsaro et al (20), assuming that: i) preferential disruption of E2 causes absence of E2 gene sequence in the PCR product following integration, ii) the copy number of both $E 2$ and $E 6$ genes should be equal when viral DNA presents in episomal form, and iii) $E 2$ copy numbers are smaller than that of $E 6$ in concomitant form.

Amplifications of HPV-16 E2 gene (76 bp) and E6 gene (81 bp) in the presence of E2- and E6-specific hybridization probes, respectively, were performed as reported before (20). In brief, the PCR analysis was performed in a $25-\mu 1$ mixture containing 1X TaqMan Master Mix (Applied Biosystems), $300 \mathrm{nM}$ of primers, $100 \mathrm{nM}$ of dual-labeled (5_FAM and 3_TAMRA) E2 or E6 fluorescence hybridization probe, and 1-2 $\mu 1$ of DNA template. The primers used were as follows: 5'-GAG AAA CTG CAA TGT TTC AGG ACC-3' for E6F, 5'-TGT ATA GTT GTT TGC AGC TCT GTG C-3' for E6R, 5'-AAC GAA GTA TCC TCT CCT GAA ATT ATT AG-3' for E2F, and 5'-CCA AGG CGA CG GCT TTG-3' for E2R. The probes used were: CAC CCC GCC GCG ACC CAT A for E2 and CAG GAG CGA CCC AGA AAG TTA CCA CAG TT for E6. After activation of the AmpliTaq Gold DNA polymerase and the denaturation of the nucleic acids by heating for $10 \mathrm{~min}$ at $95^{\circ} \mathrm{C}, 40$ cycles of denaturation at $95^{\circ} \mathrm{C}$ for $15 \mathrm{sec}$ and annealing-extension at $60^{\circ} \mathrm{C}$ for $1 \mathrm{~min}$ were carried out. Serial dilutions of full-length HPV-16-pUC19 plasmid DNA, containing equivalent amounts of E2 and E6 genes from 86 to 862 million copies per reaction, served as a standard control. DNA extracted from cervical carcinoma cell line, $\mathrm{SiHa}$, harboring 1-2 copies of purely integrated form of HPV-16 
Table I. Characteristics of the subjects in the present study.

\begin{tabular}{|c|c|c|c|c|c|c|}
\hline & \multicolumn{3}{|c|}{ Adenocarcinoma } & \multicolumn{3}{|c|}{ Squamous cell carcinoma } \\
\hline & Total & High-risk HPVa & P-value ${ }^{b}$ & Total & High-risk HPVa & P-value ${ }^{b}$ \\
\hline No. of cases & 30 & 9 & & 27 & 2 & \\
\hline \multicolumn{7}{|l|}{ Age (years) } \\
\hline Mean & 65 & 65 & & 68 & 72 & \\
\hline $\mathrm{SD}$ & 8 & 7 & & 6 & 8 & \\
\hline Youngest & 46 & 51 & & 52 & 66 & \\
\hline Oldest & 78 & 72 & & 80 & 78 & \\
\hline $\operatorname{Sex}(\%)$ & & & 0.229 & & & 1.000 \\
\hline Female & 17 & $7(41)$ & & 1 & $0 \quad(0)$ & \\
\hline Male & 13 & $2(15)$ & & 26 & $2(8)$ & \\
\hline Smoking (\%) & & & 1.000 & & & 1.000 \\
\hline Non-smoker & 16 & $5(31)$ & & 1 & $0 \quad(0)$ & \\
\hline Smoker & 14 & $4(29)$ & & 26 & $2(8)$ & \\
\hline $\mathrm{T}$ factor $(\%)$ & & & 0.760 & & & 0.481 \\
\hline $\mathrm{T} 1$ & 15 & $4(27)$ & & 8 & $0 \quad(0)$ & \\
\hline $\mathrm{T} 2$ & 10 & $4(40)$ & & 13 & $1(8)$ & \\
\hline $\mathrm{T} 3$ & 0 & & & 2 & $0 \quad(0)$ & \\
\hline $\mathrm{T} 4$ & 5 & $1(20)$ & & 4 & $1(25)$ & \\
\hline $\mathrm{N}$ factor $(\%)$ & & & 0.864 & & & 1.000 \\
\hline No & 18 & $5(28)$ & & 14 & $1 \quad(7)$ & \\
\hline N1 & 7 & $2(29)$ & & 5 & $0 \quad(0)$ & \\
\hline $\mathrm{N} 2$ & 5 & $2(40)$ & & 7 & $1(14)$ & \\
\hline N3 & 0 & & & 1 & $0 \quad(0)$ & \\
\hline $\mathrm{M}$ factor $(\%)$ & & & 0.517 & & & \\
\hline M0 & 28 & $8(29)$ & & 27 & $2(7)$ & \\
\hline M1 & 2 & $1(50)$ & & 0 & & \\
\hline \multicolumn{7}{|l|}{ Histological } \\
\hline differentiation $(\%)^{\mathfrak{c}}$ & & & 0.419 & & & 0.316 \\
\hline Well & 19 & $7(37)$ & & 8 & $0 \quad(0)$ & \\
\hline Moderate & 11 & $2(18)$ & & 11 & $2(18)$ & \\
\hline Poor & 0 & & & 8 & $0 \quad(0)$ & \\
\hline
\end{tabular}

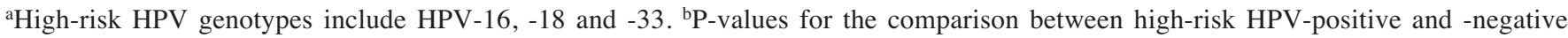

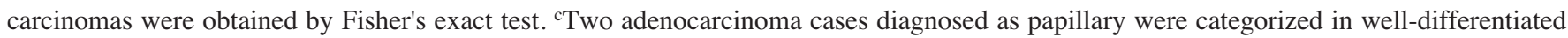
type of tumor.

gene with disruption of the $E 2$ gene, was used as controls for E2 (negative) and E6 (positive) amplification. Each HPV-16positive specimen was assayed two or three times.

Real-time PCR for the $\beta$-globin gene was also performed by 2 X QuantiTect SYBR Green PCR kit (Qiagen, Hilden, Germany) using PC03/PC04 primers to adjust the differences in the amount of input genomic DNA between samples. A 7-fold dilution series of a human DNA control (Dynal, Ltd., Bromborough, Wirral, Merseyside, UK) was used to generate the standard curve. The amount of $\beta$-globin DNA present in each sample was divided by the weight of one genome equivalent (i.e., $6.6 \mathrm{pg} / \mathrm{cell}$ ) and a factor of 2 (since there are 2 copies of $\beta$-globin DNA/genome equivalent or cell) to obtain the number of genome equivalents or cell in the sample. Viral loads in each specimen were expressed as the number of HPV copies per cell.

p16 ${ }^{I N K 4 a}, p R b$ and p53 protein immunohistochemical staining. Sections of paraffin-embedded block with the thickness of 2-3 $\mu \mathrm{m}$ were placed on silane-coated glass slides, and deparaffinized by passage through xylene. After rinsing the slides with ethanol, the endogenous peroxidase activity was blocked by incubation with $0.3 \% \mathrm{H}_{2} \mathrm{O}_{2} /$ methanol for $30 \mathrm{~min}$. The slides were then rehydrated by adding $0.01 \mathrm{~mol} / 1$ sodium phosphate/ citrate buffer, $\mathrm{pH} 8.0$, and microwaved at $95^{\circ} \mathrm{C}$ for $5 \mathrm{~min}$.

For antigen retrieval, the slides were heated in $0.01-\mathrm{M}$ citrate buffer, $\mathrm{pH} 6.0$, at $95^{\circ} \mathrm{C}$ for $30 \mathrm{~min}$. After rinsing in $0.01 \mathrm{~mol} / \mathrm{l}$ phosphate-buffered saline (PBS), $\mathrm{pH} 7.4$, non- 
Table II. HPV genotypes and expressions of p53, pRb and p16 $6^{\text {INK4a }}$ in HPV-positive lung carcinomas.

\begin{tabular}{|c|c|c|c|c|c|c|c|}
\hline \multirow[b]{2}{*}{ Case } & \multirow[b]{2}{*}{ Sex } & \multirow[b]{2}{*}{ Age } & \multirow[b]{2}{*}{ Histology } & \multirow[b]{2}{*}{ HPV genotype } & \multicolumn{3}{|c|}{ Expression } \\
\hline & & & & & p53 (\%) & $\mathrm{pRb}(\%)$ & $\mathrm{p} 16^{\mathrm{INK} 4 \mathrm{a}}(\%)$ \\
\hline 1 & Male & 69 & $\mathrm{AC}$ & 6,16 & 0 & 60 & 70 \\
\hline 2 & Female & 51 & $\mathrm{AC}$ & 33 & 70 & 20 & $<5$ \\
\hline 3 & Female & 70 & $\mathrm{AC}$ & 16 & 80 & 80 & 10 \\
\hline 4 & Female & 62 & $\mathrm{AC}$ & 16,18 & 0 & $\mathrm{NA}^{\mathrm{a}}$ & $\mathrm{NA}^{\mathrm{a}}$ \\
\hline 5 & Female & 72 & $\mathrm{AC}$ & 16 & $<5$ & 30 & 70 \\
\hline 6 & Female & 71 & $\mathrm{AC}$ & 16 & $>90$ & 20 & $>90$ \\
\hline 7 & Female & 69 & $\mathrm{AC}$ & 16 & $<5$ & 30 & 50 \\
\hline 8 & Female & 59 & $\mathrm{AC}$ & 16,6 & $<5$ & 30 & 60 \\
\hline 9 & Male & 63 & $\mathrm{AC}$ & 16 & $>90$ & $>90$ & $>90$ \\
\hline 10 & Male & 72 & SQC & 6 & 90 & 10 & $>90$ \\
\hline 11 & Male & 60 & SQC & 6 & 70 & $>90$ & $<5$ \\
\hline 12 & Male & 78 & SQC & 16 & $>90$ & $>90$ & 5 \\
\hline 13 & Male & 66 & SQC & 16 & $<5$ & 60 & $>90$ \\
\hline
\end{tabular}

${ }^{\mathrm{a}} \mathrm{pRb}$ and $\mathrm{p} 16^{\mathrm{INK} 4 \mathrm{a}}$ expressions for Case 4 were not examined due to limitation of tumor specimens.

specific antibody binding was reduced by incubating the sections with $10 \%$ fetal bovine serum in PBS for $30 \mathrm{~min}$. Then, the sections were incubated overnight at $4^{\circ} \mathrm{C}$ with a mouse monoclonal antibody of $\mathrm{p} 16^{\mathrm{INK} 4 \mathrm{a}}(1: 200$ dilutions, GST-p16 ${ }^{\mathrm{INK} 4}$, PharMingen International, San Jose, USA), p53 (1:50 dilutions, DO-7, Dako Co., Ltd., Kyoto, Japan) or pRB (1:50 dilutions, NCL-RB, Novocastra Laboratories Ltd., Newcastle, UK). After washing thoroughly with PBS, the slides were incubated with biotinylated horse anti-mouse IgG for $30 \mathrm{~min}$, and then with a 1:100 dilution of the avidinbiotin-peroxidase complex (Vectastain elite ABC kit, Vector Laboratories, Burlingame, CA) for an additional $30 \mathrm{~min}$. The peroxidase signal was visualized by treatment with DAB substrate-chromogen system (Dako Corp., Carpinteria, USA) for $8 \mathrm{~min}$. Finally the sections were stained lightly with hematoxylin. Nuclear staining was considered positive for $\mathrm{p} 16^{\mathrm{INK} 4 \mathrm{a}}, \mathrm{p} 53$ or $\mathrm{pRb}$ expression. In statistical analysis, the cases with $<10 \%$ carcinoma cells stained positive were classified as negative cases, and the other cases were regarded as positive cases for the expression in $\mathrm{p} 16^{\mathrm{INK} 4 \mathrm{a}}, \mathrm{p} 53$ and $\mathrm{pRb}$ proteins $(24,25)$.

Statistical analysis. We used Fisher's exact test for the analyses of categorical variables. P-values for trend were based on robust standard errors obtained from logistic regression models. Geometric mean of viral copy was also calculated. All statistical procedure was performed by Stata software, version 8.1. (Stata Corp., College Station, USA) or StatXact 4 (Cytel Software Corp., USA). All P-values presented are two-sided.

\section{Results}

In the present study, we examined the presence of HPV genomes in $30 \mathrm{AC}$ and $27 \mathrm{SQC}$ cases. Clinicopathological features of those cases are summarized in Table I. High-risk
HPV DNA was detected in 9 out of 30 AC samples (30\%) and 2 out of 27 SQC samples (7\%), by PCR using SPF10 primers and by INNO-LiPA HPV genotyping assay. The difference of high-risk HPV detection rates between ACs and SQCs was statistically significant $(\mathrm{P}=0.044$, Fisher's exact test). Clinicopathological features of high-risk HPV-positive lung carcinoma cases are summarized in Table I. The most prevalent genotype was HPV-16, which was detected in 8 ACs $(27 \%)$ and 2 SQCs $(7 \%)$ as summarized in Table II. Two other high-risk HPV genotypes, HPV-33 and HPV-18, were detected in ACs (Cases 2 and 4). In addition, HPV-6, a low-risk type HPV, was detected in 2 ACs and 2 SQCs. The frequency of HPV-positive lung carcinomas was not related to sex, age at diagnosis, smoking, tumor stage or histological grading (data not shown).

Tumor suppressor gene expressions in HPV-positive lung carcinomas were determined by immunohistochemistry. The results of statistical analyses of those gene expressions are summarized in Table III. High-risk HPV-positive carcinomas had decreased proportions of $\mathrm{pRb}$ expressing cells $(\mathrm{P}=0.107)$ and significantly increased proportions of $\mathrm{p} 16^{\mathrm{INK} 4 \mathrm{a}}$ expressing cells $(\mathrm{P}=0.031)$ when compared to HPV-negative lung carcinomas.

Table IV summarizes the viral load and physical status of HPV-16 detected in lung carcinomas. The geometric mean of viral load, determined by real-time PCR, was 0.02 per cell and was much lower than that observed in cervical cancer (geometric mean of HPV-16 = 333 copies per cell; unpublished data). HPV-16 E2/E6 ratio was also determined by real-time PCR. In $8(80 \%)$ ACs, E2 DNA was not detected. In the rest of the SQCs, E2 DNA was detected but the E2/E6 ratio was less than unity. Since there was no E2 amplification, all HPV-16-positive ACs were considered to have HPV integration into the host genome. In two HPV-16-positive SQCs, E2/E6 ratio was between zero and unity. Those carcinomas were considered to have both integrated and episomal forms 
Table III. HPV frequency by clinicopathological factors.

\begin{tabular}{|c|c|c|c|c|c|c|}
\hline & \multicolumn{2}{|c|}{ Total } & \multicolumn{2}{|c|}{ Adenocarcinoma } & \multicolumn{2}{|c|}{ Squamous cell carcinoma } \\
\hline & $\mathrm{n}$ & $\begin{array}{c}\text { High-risk HPV } \\
\text { positive }(\%)\end{array}$ & $\mathrm{n}$ & $\begin{array}{l}\text { High-risk HPV } \\
\text { positive }(\%)\end{array}$ & $\mathrm{n}$ & $\begin{array}{c}\text { High-risk HPV } \\
\text { positive }(\%)\end{array}$ \\
\hline Total & 57 & $11(19)$ & 30 & $9(30)$ & 27 & $2(7)$ \\
\hline \multicolumn{7}{|l|}{ p53 (\%) } \\
\hline$<10$ & 28 & $6(21)$ & 16 & $5(31)$ & 12 & $1(8)$ \\
\hline $10-49$ & 5 & $0 \quad(0)$ & 3 & $0 \quad(0)$ & 2 & $0 \quad(0)$ \\
\hline $50-89$ & 8 & $2(25)$ & 5 & $2(40)$ & 3 & $0(0)$ \\
\hline$\geq 90$ & 16 & $3(19)$ & 6 & $2(33)$ & 10 & $1(10)$ \\
\hline$P$ for trend ${ }^{a}$ & & 0.893 & & 0.875 & & 1.000 \\
\hline \multicolumn{7}{|l|}{$\mathrm{pRb}(\%)^{\mathrm{b}}$} \\
\hline$<10$ & 1 & $0 \quad(0)$ & 0 & $0 \quad(0)$ & 1 & $0 \quad(0)$ \\
\hline $10-49$ & 11 & $5(45)$ & 8 & $5(63)$ & 3 & $0 \quad(0)$ \\
\hline $50-89$ & 22 & $3(14)$ & 12 & $2(17)$ & 10 & $1(10)$ \\
\hline$\geq 90$ & 21 & $2(10)$ & 8 & $1(13)$ & 13 & $1(8)$ \\
\hline$P$ for trend ${ }^{a}$ & & 0.107 & & 0.053 & & 1.000 \\
\hline \multicolumn{7}{|l|}{$\mathrm{p} 16^{\mathrm{INK} 4 \mathrm{a}}(\%)^{\mathrm{c}}$} \\
\hline$<10$ & 26 & $2(8)$ & 11 & 1 (9) & 15 & $1(7)$ \\
\hline $10-49$ & 12 & $1 \quad(8)$ & 4 & $1(25)$ & 8 & $0 \quad(0)$ \\
\hline $50-89$ & 11 & $4(36)$ & 10 & $4(40)$ & 1 & $0 \quad(0)$ \\
\hline$\geq 90$ & 7 & $3(43)$ & 4 & $2(50)$ & 3 & $1(33)$ \\
\hline$P$ for trend ${ }^{a}$ & & 0.031 & & 0.066 & & 0.237 \\
\hline
\end{tabular}

aP-values for trend were obtained from Cochran-Armitage trend test, using StatXact 4. ${ }^{\mathrm{p} p R b}$ expression for one HPV-negative and one HPV-16positive case was not examined because of the limitation of tumor specimens. ${ }^{c}$ p $16^{\text {INK4a }}$ expression for one HPV-16-positive case was not examined because of the limitation of tumor specimens.

Table IV. Viral load and E2/E6 of HPV-16 detected in HPV-16-positive lung carcinomas.

\begin{tabular}{rllll}
\hline Case & Histology & $\begin{array}{c}\text { HPV-16 E6 } \\
\text { copies cell }\end{array}$ & E2/E6 & $\begin{array}{c}\text { Physical } \\
\text { status }\end{array}$ \\
\hline 1 & AC & 0.2 & No E2 & Integrated \\
3 & AC & $7.09 \mathrm{E}-07$ & No E2 & Integrated \\
4 & AC & 0.2 & No E2 & Integrated \\
5 & AC & 0.001 & No E2 & Integrated \\
6 & AC & 0.5 & No E2 & Integrated \\
7 & AC & 0.01 & No E2 & Integrated \\
8 & AC & 0.01 & No E2 & Integrated \\
9 & AC & 0.4 & No E2 & Integrated \\
12 & SQC & 0.10 & 0.2 & Mixed \\
13 & SQC & 0.03 & 0.1 & Mixed \\
\hline
\end{tabular}

of HPV-16 DNAs. Neither viral load nor physical status of HPV-16 was related to the expression of $\mathrm{p} 16^{\mathrm{INK} 4 \mathrm{a}}$ or $\mathrm{pRb}$.

In addition to those cases, we examined primary tumors obtained from recurrent $\mathrm{AC}$ cases treated with gefitinib
(Table V). HPV was negative in all of the gefitinib nonresponsive ACs $(n=12)$, but was positive in 6 or $75 \%$ of 8 ACs with complete or partial response. One gefitinib nonresponsive AC (case G11) was HPV-16 positive in the adjacent normal tissues but HPV negative in its cancer lesion. The difference of HPV-positive frequency between gefitinib nonresponsive and responsive ACs was statistically significant $(\mathrm{P}<0.001$, Fisher's exact test $)$. Predominant HPV genotype in gefitinib-responsive ACs was HPV-16, which was observed in four cases. In addition, HPV-18 was detected in the remaining 2 ACs. There was no significant association between expressions of tumor suppressor genes and HPV presence in those recurrent ACs. Real-time PCR analysis for HPV-16-positive cases showed that geometric mean of the viral load was 0.064 (95\% CI: $0.008,0.546)$ copies per cell. In none of the HPV-16-positive gefitinib-responsive ACs, E2 DNA was detected (Table VI).

\section{Discussion}

The present study suggests that high-risk HPV may be more strongly related to ACs in Japan when compared to SQCs. Our finding is compatible with a Taiwanese study that detected high-risk HPV from ACs among non-smoking women at a 
Table V. HPV frequency among the patients with adenocarcinoma ${ }^{\mathrm{a}}$ who received gefitinib treatment.

\begin{tabular}{|c|c|c|c|c|c|c|c|c|c|c|}
\hline \multirow[b]{2}{*}{ Case } & \multirow[b]{2}{*}{ Sex } & \multirow[b]{2}{*}{ Age } & \multirow{2}{*}{$\begin{array}{l}\text { Responsiveness } \\
\text { to gefitinib }\end{array}$} & \multirow[b]{2}{*}{ HPV } & \multirow{2}{*}{$\begin{array}{l}\text { Tumor } \\
\text { grade }\end{array}$} & \multirow{2}{*}{$\begin{array}{l}\text { Period between } \\
\text { operation and } \\
\text { recurrence (days) }\end{array}$} & \multirow{2}{*}{$\begin{array}{l}\text { Side-effects } \\
\text { of gefitinib }\end{array}$} & \multicolumn{3}{|c|}{ Expression (\%) } \\
\hline & & & & & & & & p53 & $\mathrm{pRb}$ & $\mathrm{p} 16^{\mathrm{INK} 4 \mathrm{a}}$ \\
\hline G1 & M & 67 & CR & Negative & Poorly & 219 & Pruritus, eczema & 90 & 0 & 90 \\
\hline G2 & M & 64 & CR & HPV-18 & Moderate & 300 & Diarrhea & 0 & 50 & 50 \\
\hline G3 & $\mathrm{F}$ & 78 & PR & Negative & Well & 494 & Pruritus, fatigue & 0 & 0 & 0 \\
\hline G4 & $\mathrm{F}$ & 66 & PR & HPV-16 & Well & 359 & Pruritus, eczema & 0 & 0 & 10 \\
\hline G5 & $\mathrm{F}$ & 68 & PR & HPV-18 & Well & 141 & Eczema, diarrhea & 0 & 0 & 0 \\
\hline G6 & $\mathrm{F}$ & 72 & PR & HPV-16 & Well & 860 & Dry skin, diarrhea & 10 & 0 & 10 \\
\hline G7 & $\mathrm{F}$ & 59 & PR & HPV-16 & Well & 2393 & Diarrhea, pigmentation & 0 & 0 & 0 \\
\hline G8 & $\mathrm{F}$ & 55 & PR & HPV-16 & Moderate & 2017 & Diarrhea & 0 & 0 & 50 \\
\hline G9 & M & 65 & Stable disease & Negative & Moderate & 186 & $\begin{array}{l}\text { Pruritus, eczema, } \\
\text { liver disfunction }\end{array}$ & 0 & 0 & 0 \\
\hline G10 & M & 83 & Stable disease & Negative & Well & 885 & Fatigue & 90 & 0 & 10 \\
\hline G11 & $\mathrm{M}$ & 50 & Stable disease & Negative $^{c}$ & Well & 1745 & Interstitial pneumonia & 0 & 50 & 0 \\
\hline G12 & $\mathrm{F}$ & 62 & Stable disease & Negative & Well & 1938 & Diarrhea, pruritus & 40 & 0 & 60 \\
\hline G13 & $\mathrm{M}$ & 62 & Progressive & Negative & Poorly & 46 & None & 0 & 0 & 10 \\
\hline G14 & $\mathrm{M}$ & 78 & Progressive & Negative & Well & 508 & None & 0 & 0 & 0 \\
\hline G15 & $\mathrm{M}$ & 46 & Progressive & Negative & Moderate & 592 & Eczema & 0 & 10 & 0 \\
\hline G16 & M & 48 & Progressive & Negative & Poorly & 1771 & $\begin{array}{l}\text { Fatigue, pruritus, } \\
\text { pigmentation }\end{array}$ & 0 & 0 & 0 \\
\hline G17 & M & 53 & Progressive & Negative & Moderate & Inoperable & None & $\mathrm{NA}^{\mathrm{d}}$ & $\mathrm{NA}^{\mathrm{d}}$ & $\mathrm{NA}^{\mathrm{d}}$ \\
\hline G18 & $\mathrm{F}$ & 65 & Progressive & Negative & Moderate & 204 & None & 50 & 0 & 0 \\
\hline G19 & $\mathrm{F}$ & 65 & Progressive & Negative & Moderate & 888 & $\begin{array}{l}\text { Dry skin, diarrhea, } \\
\text { liver disfunction }\end{array}$ & 0 & 20 & 0 \\
\hline G20 & $\mathrm{F}$ & 68 & Progressive & Negative & Poorly & 294 & Impetigo & 0 & 0 & 90 \\
\hline
\end{tabular}

${ }^{a}$ All cases were adenocarcinomas. Case 12 had both adenocarcinomas and squamous cell carcinoma of lung. ${ }^{b} \mathrm{CR}$, complete response with disappearance of the tumor; PR, partial response with $>50 \%$ decrease of the tumor; progressive, $>25 \%$ increase of the tumor or appearance of new lesion(s); and stable disease, neither partial response nor progressive disease. ${ }^{c} \mathrm{HPV}$ genome was not detected in carcinoma tissues, but HPV-16 genome was detected in adjusting normal lung tissues. ${ }^{\mathrm{d}}$ Tumor specimen of Case G17 was limited and immunohistochemical staining was not performed.

relatively high frequency (4). However, the present study did not show a predisposition of high-risk HPV to women or non-smokers. Other important findings in the present study are a significant decrease of $\mathrm{pRb}$ expressing cells $(\mathrm{P}=0.107)$ and a significant increase of $\mathrm{p} 16^{\mathrm{INK} 4 \mathrm{a}}$ expressing cells $(\mathrm{P}=0.031)$ in lung carcinomas with high-risk HPV genome when compared to high-risk HPV-negative carcinomas. Although those findings suggest an etiological role of highrisk HPV in lung carcinogenesis, the low viral load, as observed in the present study, casts a doubt on such a notion. It should also be noted that high-risk HPV-positive lung carcinomas did not have clear expression of HPV-16 E6 protein in immunohistochemistry analysis (data not shown). A possible explanation for those findings is the presence of an unknown factor that affects the expressions of $\mathrm{pRb}$ and p16 $6^{\mathrm{INK} 4 \mathrm{a}}$ in carcinomas, and, in addition, induces high-risk HPV infection in carcinoma cells. Another possible explanation for low viral load is the 'hit and run' hypothesis, where viral genome is necessary for initiation but not for maintenance of cellular transformation (26). Such a mechanism can explain the observation that only small portions of virustransformed cells harbored viral genome as was reported by studies on cell transformation by bovine papillomavirus (27) and HPV-18 (28). It was also hypothesized that the deregulated high-risk HPV E6-E7 expression induces chromosomal instability, resulting in HPV genome integration in the affected cell (29). It is suspected that the chromosome instability may give rise to more malignant cancer cells with a selective growth advantage (30). Those malignant cells with chromosome instability may tend to lose HPV-integrated chromosome or the HPV-integrated part of chromosome after many cycles of cell replications due to chromosome instability.

The sensitivity of lung ACs to gefitinib and erlotinib, small-molecule EGFR specific tyrosine kinase inhibitors, are known to be associated with EGFR mutations, which include i) exon 19 mutations characterized by in-frame deletions of 
Table VI. Viral load and physical status of HPV detected in recurrent adenocarcinomas treated with gefitinib.

\begin{tabular}{lcclc}
\hline Case & $\begin{array}{c}\text { HPV } \\
\text { genotype }\end{array}$ & Viral load & \multicolumn{1}{c}{ E2/E6 } & $\begin{array}{c}\text { Physical } \\
\text { status }\end{array}$ \\
\hline G2 & 18 & 0.00425 & Not examined & \\
G4 & 16 & 0.27360 & No E2 & Integrated \\
G5 & 18 & 0.01140 & Not examined & \\
G6 & 16 & 0.02621 & No $E 2$ & Integrated \\
G7 & 16 & 0.14510 & No $E 2$ & Integrated \\
G8 & 16 & 0.01650 & No E2 & Integrated \\
G11 & 16 & 0.00002 & No $E 2$ & Integrated \\
\hline
\end{tabular}

${ }^{a} \mathrm{HPV}$ genome was not detected in carcinoma tissues, but HPV-16 genome was detected in adjusting normal lung tissues.

amino acids $747-750$, accounting for $45 \%$ of mutations; ii) exon 21 mutations resulting in L858R substitutions, accounting for $40-45 \%$ of mutations; and iii) mutations involving exons 18 and 20, accounting fot the remaining $10 \%$ (31). Interestingly, EGFR mutations are more prevalent in women, never smokers, patients of Asian ethnicity, and those with AC histology $(5,6)$. Since these clinicopathological features seemed similar to that reported for HPVpositive ACs in Taiwan (4), we examined gefitinibresponsive and non-responsive ACs for HPV DNA. Highrisk HPV was detected in $75 \%$ of gefitinib-responsive ACs whereas none of gefitinib non-responsive ACs was HPV positive. Our finding suggests that the sensitivity to HPV infection may be associated with genetic backgrounds relating to EGFR mutations (31). Interestingly, Takeuchi et al (32) reported that lung ACs can be classified into two major types: terminal respiratory unit (TRU) type and non-TRU type. They showed the presence of a significantly higher frequency of EGFR mutation in TRU type ACs when compared to nonTRU type ACs. It is of interest to examine the association of HPV infection and TRU-type ACs. HPV E5 protein is known to be an EGFR activator (33). However, HPV E5 gene in cervical carcinomas is frequently lost or underexpressed after integration when compared with E6 and E7 genes, which encode important oncoproteins of high-risk HPV (34). In the present study, EGFR was not up-regulated in HPV-positive ACs when compared to HPV-negative ACs by immunostaining (data not shown).

Somatic K-Ras mutation has been assessed as another potential marker for the response to anti-EGFR agents (35). Since Noutsou et al (36) pointed out the involvement of highrisk HPVs in the carcinogenesis of the lung in cooperation with $K$-Ras mutation, it is worthwhile to examine the frequency of $K$-Ras mutation in HPV-positive and -negative lung carcinomas.

The transmission route of the HPV detected in lung carcinomas is not clear. Some researchers suspect that HPV detected in lung carcinoma may originate in the uterine cervix and spread to the lung tissue via the bloodstream (37). However, a study in Latin America, which compared the second cancer risk of 335 women with invasive cervical cancer and their first degree relatives, did not find any increase in lung cancer risk among cervical cancer patients (38). Since HPV infects the oral mucosa, and subsequently, the larynx and the bronchial tissue (39), HPV infection of the lung tissue may be through the upper aero-digestive tract.

The present study also showed that HPV-16 detected in lung carcinomas are frequently integrated, confirming the finding of our previous report examining lung carcinomas in Chile (12). However, the following three points should be taken into account: i) disrupted viral copies may be flanked by intact viral copies (40), ii) HPV integration does not always cause E2 disruption $(41,42)$; and iii) more than a 10 fold excess of episomal form to integrated form of the virus interferes with E2 amplification, regardless the amount of viral DNA, resulting in lower E2/E6 ratios (43). Those factors tend to mask the presence of the integrated form HPV. However, since we found no carcinoma with the exclusive presence of episomal HPV-16 (E2/E6 ratio being equal to or higher than unity), it can be concluded that all the HPV-positive carcinomas had integrated-form of HPV with or without episomal HPV DNA.

In conclusion, the present study suggests that high-risk HPV may be more strongly related to ACs, particularly gefitinib-responsive ACs, when compared to SQCs. However, the low viral load makes it difficult to determine the etiological significance of these findings. Further studies seem warranted to elucidate the etiological role of HPV in lung carcinogenesis.

\section{Acknowledgements}

This study was supported by Grants-in-Aid for Scientific Research on Priority Areas (17015037) of the Ministry of Education, Culture, Sports, Science and Technology, Japan.

\section{References}

1. Klein F, Amin Kotb WF and Petersen I: Incidence of human papillomavirus in lung cancer. Lung Cancer 65: 13-18, 2009.

2. Syrjanen KJ: HPV infections and lung cancer. J Clin Pathol 55: 885-891, 2002.

3. Miyagi J, Tsuhako K, Kinjo T, Iwamasa T and Hirayasu T: Recent striking changes in histological differentiation and rate of human papillomavirus infection in squamous cell carcinoma of the lung I Okinawa, a subtropical island in southern Japan. J Clin Pathol 53: 676-684, 2000.

4. Cheng YW, Chiou HL, Sheu GT, Hsieh LL, Chen JT, Chen CY, $\mathrm{Su}$ JM and Lee H: The association of human papillomavirus 16/18 infection with lung cancer among non-smoking Taiwanese women. Cancer Res 61: 2799-2803, 2001.

5. Pao W, Miller V, Zakowski M, Doherty J, Politi K, Sarkaria I, Singh B, Heelan R, Rusch V, Fulton L, Mardis E, Kupfer D, Wilson R, Kris M and Varmus H: EGF receptor gene mutations are common in lung cancers from 'never smokers' and are associated with sensitivity of tumors to gefitinib and erlotinib. Proc Natl Acad Sci USA 101: 13306-13311, 2004

6. Miller VA, Kris MG, Shah N, Patel J, Azzoli C, Gomez J, Krug LM, Pao W, Rizvi N, Pizzo B, Tyson L, Venkatraman E, Ben-Porat L, Memoli N, Zakowski M, Rusch V and Heelan RT: Bronchioloalveolar pathologic subtype and smoking history predict sensitivity to gefitinib in advanced non-small-cell lung cancer. J Clin Oncol 22: 1103-1109, 2004.

7. Walboomers JM, Jacobs MV, Manos MM, Bosch FX, Kummer JA, Shah KV, Snijders PJ, Peto J, Meijer CJ and Munoz N: Human papillomavirus is a necessary cause of invasive cervical cancer worldwide. J Pathol 189: 12-19, 1999. 
8. Bosch FX, Manos MM, Munoz N, Sherman M, Jansen AM, Peto J, Schiffman MH, Moreno V, Kurman R and Shah KV: Prevalence of human papillomavirus in cervical cancer: a worldwide perspective. International Biological Study on Cervical Cancer (IBSCC) Study Group. J Natl Cancer Inst 87: 796-802, 1995

9. Bosch FX, Lorincz A, Munoz N, Meijer C and Shah KV: The causal relationship between human papillomavirus and cervical cancer. J Clin Pathol 55: 244-265, 2002.

10. IARC: Monographs on the evaluation of carcinogenic risks to humans. In: Human Papillomaviruses. Vol 90. International Agency for Research on Cancer, Lyon, 2007.

11. Hudelist G, Manavi M, Pischinger KI, Watkins-Riedel T, Singer CF, Kubista E and Czerwenka KF: Physical state and expression of HPV DNA in benign and dysplastic cervical tissue: different levels of viral integration are correlated with lesion grade. Gynecol Oncol 92: 873-880, 2004.

12. Aguayo F, Castillo A, Koriyama C, Higashi M, Itoh T, Capetillo M, Shuyama K, Corvalan A, Eizuru Y and Akiba S: Human papillomavirus-16 is integrated in lung carcinomas: a study in Chile. Br J Cancer 97: 85-91, 2007.

13. Arias-Pulido H, Peyton CL, Joste NE, Vargas H and Wheeler CM: Human papillomavirus type 16 integration in cervical carcinoma in situ and in invasive cervical cancer. J Clin Microbiol 44: 1755-1762, 2006.

14. Hoppe-Seyler F and Butz K: Cellular control of human papillomavirus oncogene transcription. Mol Carcinog 10: 134-141, 1994.

15. Barbosa MS: The oncogenic role of human papillomavirus proteins. Crit Rev Oncog 7: 1-18, 1996.

16. Cheng YW, Wu MF, Wang J, Yeh KT, Goan YG, Chiou HL, Chen CY and Lee H: Human papillomavirus 16/18 E6 oncoprotein is expressed in lung cancer and related with p53 inactivation. Cancer Res 67: 10686-10693, 2007.

17. Fiedler M, Muller-Holzner E, Viertler HP, Widschwendter A, Laich A, Pfister G, Spoden GA, Jansen-Durr P and Zwerschke W: High level HPV16 E7 oncoprotein expression correlates with reduced $\mathrm{pRb}$-levels in cervical biopsies. FASEB J 18: 1120-1122, 2004.

18. Khleif SN, De Gregori J, Yee C, Otterson GA, Kaye FJ, Nevins JR and Howley PM: Inhibition of cyclin D-CDK4/ CDK6 activity is associated with an E2F-mediated induction of cyclin kinase inhibitor activity. Proc Natl Acad Sci USA 93: 4350-4354, 1996.

19. Sano T, Oyama T, Kashiwabara K, Fukuda T and Nakajima T: Expression status of p16 protein is associated with human papillomavirus oncogenic potential in cervical and genital lesions. Am J Pathol 153: 1741-1748, 1998.

20. Peitsaro P, Johansson B and Syrjanen S: Integrated human papillomavirus type 16 is frequently found in cervical cancer precursors as demonstrated by a novel quantitative real-time PCR technique. J Clin Microbiol 40: 886-891, 2002.

21. The Japan Lung Cancer Society: Classification of Lung Cancer. 1st edition. Kanehara \& Co., Ltd., Tokyo, pp54-65, 2000.

22. Kleter B, van Doorn LJ, ter Schegget J, Schrauwen L, van Krimpen K, Burger M, ter Harmsel B and Quint W: Novel short-fragment PCR assay for highly sensitive broad-spectrum detection of anogenital human papillomaviruses. Am J Pathol 153: 1731-1739, 1998

23. Kleter B, van Doorn LJ, Schrauwen L, Molijin A, Sastrowijoto S, ter Schegget J, Lindeman J, ter Harmsel B, Burger M and Quint W: Development and clinical evaluation of a highly sensitive PCR-reverse hybridization line probe assay for detection and identification of anogenital human papillomavirus. J Clin Microbiol 37: 2508-2517, 1999.

24. Ralhan R, Mathew R, Arora S, Bahl R, Shukla NK and Mathur M: Frequent alterations in the expression of tumor suppressor genes $\mathrm{p} 16 \mathrm{INK} 4 \mathrm{~A}$ and $\mathrm{pRb}$ in esophageal squamous cell carcinoma in the Indian population. J Cancer Res Clin Oncol 126: 655-660, 2000 .

25. Xu H, Lu DW, El-Mofty SK and Wang HL: Metachronous squamous cell carcinomas evolving from independent oropharyngeal and pulmonary squamous papilomas: association with human papillomavirus 11 and lack of aberrant $\mathrm{p} 53, \mathrm{Rb}$ and $\mathrm{p} 16$ protein expression. Hum Pathol 35: 1419-1422, 2004.
26. Skinner GR: Transformation of primary hamster embryo fibroblasts by type 2 simplex virus: evidence for a 'hit and run' mechanism. Br J Exp Pathol 57: 361-376, 1976.

27. Smith KT and Campo MS: 'Hit and run' transformation of mouse $\mathrm{C} 127$ cells by bovine papillomavirus type 4: the viral DNA is required for the initiation but not for maintenance of the transformed phenotype. Virology 164: 39-47, 1988.

28. Iwasaka T, Hayashi Y, Yokoyama M, Hara K, Matsuo N and Sugimori H: 'Hit and run' oncogenesis by human papillomavirus type 18 DNA. Acta Obstet Gynecol Scand 71: 219-223, 1992.

29. Vinokurova S, Wentzensen N, Kraus I, Klaes R, Driesch C, Melsheimer P, Kisseljov F, Durst M, Schneider A and von Knebel Doeberitz M: Type-dependent integration frequency of human papillomavirus genomes in cervical lesions. Cancer Res 68: 307-313, 2008

30. Masuda A and Takahashi T: Chromosome instability in human lung cancers: possible underlying mechanisms and potential consequences in the pathogenesis. Oncogene 21: 6884-6897, 2002.

31. Sharma SV, Bell DW, Settleman J and Haber DA: Epidermal growth factor receptor mutations in lung cancer. Nat Rev Cancer 7: 169-181, 2007

32. Takeuchi T, Tomida S, Yatabe Y, Kosaka T, Osada H, Yanagisawa K, Mitsudomi T and Takahashi T: Expression profile-defined classification of lung adenocarcinoma shows close relationship with underlying major genetic changes and clinicopathologic behaviors. J Clin Oncol 24: 1679-1688, 2006.

33. Tsai TC and Chen SL: The biochemical and biological functions of human papillomavirus type 16 E5 protein. Arch Virol 148: 1445-1453, 2003.

34. Zur Hausen H: Disrupted dichotomous intracellular control of human papillomavirus infection in cancer of the cervix. Lancet 343: 955-957, 1994.

35. Linardou H, Dahabreh I, Kanaloupiti D, Siannis F, Bafaloukos D, Kosmidis P, Papadimitriou CA and Murray S: Assessment of somatic K-RAS mutations as a mechanism associated with resistance to EGFR-targeted agents: a systematic review and meta-analysis of studies in advanced non-small cell lung cancer and metastatic colorectal cancer. Lancet Oncol 9: 962-972, 2008.

36. Noutsou A, Koffa M, Ergazaki M, Siafakas NM and Spandidos DA: Detection of human papillomavirus (HPV) and $\mathrm{K}$-ras mutations in human lung carcinomas. Int J Oncol 8: 1089-1093, 1996.

37. Cheng YW, Chiou HL, Chen JT, Chou MC, Lin TS, Lai WW, Chen CY, Tsai YY and Lee H: Gender difference in human papillomarvirus infection for non-small cell lung cancer in Taiwan. Lung Cancer 46: 165-170, 2004.

38. Weber W, De Sabata MS, Paredes RM, Rodriguez G, Santos C, Sabillon JU and Zwahlen M: Cancer in first degree relatives of Latin American women with cervical cancer: a pilot study. Anticancer Res 25: 1219-1223, 2005.

39. Smith EM, Ritchie JM, Summersgill KF, Klussmann JP, Lee JH, Wang D, Haugen TH and Turek LP: Age, sexual behavior and human papillomavirus infection in oral cavity and oropharyngeal cancers. Int J Cancer 108: 766-772, 2004.

40. Jeon S, Allen-Hoffmann BL and Lambert PF: Integration of human papillomavirus type 16 into the human genome correlates with a selective growth advantage of cells. J Virol 69: 2989-2997, 1995.

41. Vernon SD, Unger ER, Miller DL, Lee DR and Reeves WC: Association of human papillomavirus type 16 integration in the E2 gene with poor disease-free survival from cervical cancer. Int J Cancer 74: 50-56, 1997.

42. Eriksson A, Herron JR, Yamada T and Wheeler CM: Human papillomavirus type 16 variant lineage characterized by nucleotide sequence analysis of the E5 coding segment and the E2 hinge region. J Gen Virol 80 (Pt3): 595-600, 1999.

43. Ruutu MP, Kulmala SM, Peitsaro P and Syrjanen SM: The performance of the HPV16 real-time PCR integration assay. Clin Biochem 41: 423-428, 2008. 